FILOZOFIA

Roč. 75,2020 , č. 9

DOI: https://doi.org/10.31577/filozofia.2020.75.9.1

\title{
NATURALIZMUS V AMERICKEJ FILOZOFII A KLASICKOM PRAGMATIZME
}

EMIL VIŠŇOVSKÝ, Filozofická fakulta Univerzity Komenského v Bratislave, Katedra filozofie

a dejín filozofie, Bratislava, SR

VIŠŇOVSKÝ, E.: Naturalism in American Philosophy and Classical Pragmatism FILOZOFIA, 75, 2020, No 9, pp. $734-746$

\begin{abstract}
This is an update survey which maps the key features of naturalism as one of the central conceptions in American philosophy. Following the introduction with brief remarks on the current "naturalistic turn", the author follows up with an overview of the development of American naturalism indicating its key figures and schools as well as its key features such as realism, non-reductionism and pluralism. He then focuses on naturalism of classical pragmatism. Based on an account of Peirce, James and Dewey and their contributions, the specific characteristics of their versions are given such as anti-authoritarianism (anti-absolutism), anti-dualism, and humanism. The classical pragmatist naturalism is "cultural naturalism" overcoming the gulf between nature and culture. Its central concept is the concept of human cultural practices encompassing human transactions with nature and human creation of cultural forms.
\end{abstract}

Keywords: American philosophy - Naturalism - Pragmatism - Realism - Santayana Columbia naturalists - Peirce - James - Dewey - Cultural naturalism

\section{Úvod}

Americká filozofia a pragmatizmus stoja v pozadí renesancie naturalizmu, a to aj v d’alších filozofických smeroch, napríklad v analytickej filozofii (Kim 2003). ${ }^{1}$ Naturalistický obrat v súčasnej filozofii sa stal faktom (Stroud 1996) a univerzálnym javom (Clark 2016). Oživuje nielen staré otázky, ako je vzt’ah „ducha a prírody“ (Corrington 1992), ale nastol'uje aj novšie, ako je vzt'ah normativity a prírody (De Caro, Macarthur 2010). Tento obrat môžeme považovat' za súčast' „metafilozofického obratu“ $k$ fundamentálnym otázkam „filozofie filozofie“ (Cahill, Raleigh 2018).

Táto stat' sa sústred'uje na naturalizmus v americkej filozofii od jej počiatkov po dvadsiate storočie vrátane klasického pragmatizmu, ktorý sa sformoval v jej kontexte. Je prehl'adovou štúdiou o tom, aký typ pragmatizmu sa rozvíjal v tejto intelektuálnej

\footnotetext{
${ }^{1}$ Projekt naturalizácie v analytickej filozofii si rýchlo našiel svojich odporcov (Craig, Moreland 2000; Corradini, Galvan, Lowe 2006).
} 
tradícii, o jeho špecifikách, ktorými sa odlišuje od iných typov naturalizmu. V závere zhrniem hlavné rysy tohto naturalizmu, ktoré sú aktuálne aj v súčasnosti a rozvíjajú sa v súčasnom neopragmatizme. ${ }^{2}$ Ciel’om je načrtnút' historické zdroje konceptu nereduktívneho naturalizmu, ktorý pokladám za plauzibilný a perspektívny.

\section{Naturalizmus v dejinách americkej filozofie}

\subsection{Počiatky}

Naturalizmus je jednou z definujúcich charakteristík myslenia a kultúry v USA (Ryder 1994, 13; Eldridge 2004). V dejinách americkej filozofie má hlbšie ukotvenie a netýka sa iba pragmatizmu, ktorý z tejto tradície vyrástol. ${ }^{3} \mathrm{Už} \mathrm{v} \mathrm{počiatkoch} \mathrm{popri} \mathrm{idealizme}$ až mysticizme (supranaturalizme) puritanizmu bola $\mathrm{v}$ nej prítomná tendencia $\mathrm{k}$,,prírodnej filozofii““ (ako synonyma vedy, ale aj praktického, sekulárneho a humanistického postoja k svetu), inšpirovaná Newtonom a Lockom, ktorá sa plnšie prejavila neskôr v deizme amerického osvietenstva u T. Jeffersona a B. Franklina i d’alších. Na deizmus nadviazali osvietenské idey zdokonal'ovania človeka a vylepšovania jeho pozemských podmienok života. Vol’nomyšlienkári ako T. Paine sa väčšmi spoliehali na rozum a skúsenost' ako na vieru a autority. Napríklad Elihu Palmer (1764 - 1806) vyvolal vel'ký rozruch svojou knihou Princípy prírody (1801). Anglický imigrant, materialista a akademik Thomas Cooper (1759 - 1839), vplyvný aj v politike, obhajoval výsledky geológie proti Biblii (Fox, Kloppenberg 1995, 148). Ethan Allen (1738 - 1789) bol priam prototypom Američana, ktorý vo svojom búrlivom živote spájal myslenie (ako filozof a teológ) s praxou (ako podnikatel' a politik); v knihe Rozum (1785) ako spinozovský naturalista priamo útočil na biblickú doktrínu (Shapiro 1964). Významnejším a vplyvnejším predstavitel'om newtonovskej prírodnej filozofie bol materialista Cadwallader Colden (1688 - 1776), ktorý vydal samostatnú prácu o princípoch pohybu telies a planét (1751) a spolu s B. Franklinom bol jedným zo zakladatel'ov Americkej filozofickej spoločnosti (1742). Ďalší signatár americkej Deklarácie nezávislosti, chemik a lekár z Filadelfie Benjamin Rush (1754 - 1813), vystúpil v uvedenej spoločnosti s prednáškou o fyzikálnych príčinách morálnych vlastností (1786).

Na tento vývoj nadviazal v devätnástom storočí najprv vplyv škótskej filozofie zdravého rozumu (T. Reid, D. Stewart) v oblasti ,mentálnej“ a morálnej filozofie u takých myslitel'ov, ako boli John Witherspoon (1723 - 1794), Thomas Upham (1799 1872), Noah Porter (1811 - 1892) či James McCosh (1811 - 1894). Zároveň s tým sa rozvíjala romantická „filozofia prírody“ v rámci amerického transcendentalizmu,

\footnotetext{
${ }^{2}$ Súčasný neopragmatizmus a jeho naturalistické koncepcie budú predmetom samostatnej štúdie.

${ }^{3}$ K charakteru a vývinu americkej filozofie pozri Mihina (1992); Marsoobian, Ryder (2004).
} 
inšpirovaná nemeckým idealizmom (Emersonova esej Príroda, Thoreauov Walden). Vd'aka tomuto ukotveniu získalo poňatie prírody väčšmi estetické a existenciálne kvality. Dualizmus prírodného a spirituálneho však nebol celkom prekonaný, o čom svedčila aj vplyvná práca Horace Bushnella (1802 - 1876) o prírode a nadprirodzenom ako dvoch aspektoch Božieho poriadku (1858) (Kuklick 2001).

Zásadným impulzom pre obrat $\mathrm{k}$ naturalizmu ešte $\mathrm{v}$ poslednej tretine devätnásteho storočia bol darvinizmus (Kuklick 2001; Misak 2008). Znamenal výzvu pre všetky oblasti filozofie (i teológie), ktoré sa v tom čase začali na americkej pôde inštitucionalizovat' a profesionalizovat' zakladaním d'alších univerzít a vedeckých časopisov. Ako jeden z prvých túto situáciu reflektoval slávny Metafyzický klub, založený na Harvardovej univerzite (1872) na čele s Ch. S. Peirceom. Jeho spoluzakladatelom bol aj matematik Chauncey Wright $(1830$ - 1875), nadšený darvinista a kritik H. Spencera, ktorého eseje (1878) významne ovplyvnili všetkých klasických pragmatistov najmä ideou evolucionizmu, hoci on sám nestotožňoval vedu s naturalizmom, ale ani s idealizmom či inou doktrínou, pretože podl'a vzoru pozitivistov odmietal metafyziku ako takú (Madden 1963).

\subsection{Kolumbijská škola}

V reakcii na niektoré excesy darvinistického naturalizmu, osobitne sociálneho darvinizmu, ale rovnako aj na nový americký absolútny idealizmus, ${ }^{4}$ sa začiatkom dvadsiateho storočia sformovalo nové centrum naturalizmu na Kolumbijskej univerzite v New Yorku, kde od roku 1904 pôsobil John Dewey. Vedúcou osobnost'ou tohto centra sa stal Frederick J. E. Woodbridge $\left(1867\right.$ - 1940). Pre neho i d'alších ${ }^{5}$ sa významnou inšpiráciou stal George Santayana (1863 - 1952), žiak Williama Jamesa na Harvarde. Všetci naturalisti boli viac či menej, priamo alebo nepriamo ovplyvnení pragmatizmom, avšak hladali svoje vlastné filozofické cesty, pričom ich spoločným menovatel'om mal byt' vyváženejší variant naturalizmu, ktorý nielenže staval na Darwinovi, ale vracal sa spät' $\mathrm{k}$ Aristotelovi, Baconovi, a najmä Spinozovi. Ich

\footnotetext{
${ }^{4}$ Jeho zakladatel'om bol takisto vel'mi vplyvný a inšpiratívny harvardský profesor Josiah Royce (1855 - 1916), ovplyvnený pragmatizmom W. Jamesa. Svoju koncepciu prvýkrát vyložil v práci Náboženský aspekt filozofie (1885) a d’alej rozvinul v prednáškach Svet a jednotlivec (1899 - 1900). ${ }^{5}$ Woodbridgovou hlavnou prácou bola Esej o prírode (1940), v ktorej staval najmä na Aristotelovi. K jeho študentom patrili známi i menej známi filozofi: Irwin Edman (1896 - 1954), Herbert Schneider (1892 - 1984), John Herman Randall, Jr. (1899 - 1980), Ernest Nagel (1901 - 1985) a iní. Spomedzi nich sa metafyzickému naturalizmu najsystematickejšie venoval John Herman Randall, Jr., ktorého hlavnou prácou bola monografia Príroda a historická skúsenost' (1958). Ernest Nagel, rodák z Nového Mesta nad Váhom, rozvíjal svoj naturalizmus hlavne v kontexte filozofie vedy, ktorá bola jeho doménou; v prednáške s názvom Prehodnotenie naturalizmu, ktorú predniesol pre Americkú filozofickú asociáciu v roku 1954, sa koncentroval na vedeckú racionalitu, ktorú chápal pluralisticky (Nagel 1968, 543 - 556).
} 
najčastejším a najbližším spojencom boli rôzne formy realizmu, odmietajúce špekulatívnu filozofiu každého druhu. V tomto spojení naturalizmu a realizmu boli dokonca kritikmi pragmatizmu a hladali k nemu alternatívu. Takýmto kritickým realistom bol Roy Wood Sellars (1880 - 1973), ktorý vypracoval vlastnú koncepciu „evolučného naturalizmu“. Vychádzal z tvrdenia, že teraz, ked’ „sme už všetci naturalisti“, treba naturalizmus adekvátne filozoficky zadefinovat' (Sellars 1922, vii). Nestačí „naivné filozofovanie vedcov“, pretože naturalizmus musí byt' Weltanschauung založený na vývoji, a nie na nejakom stave vedy (napríklad vo fyzike), ktorý by sa zakonzervoval. „Evolučný naturalizmus nie je reduktívny naturalizmus“ (Sellars 1922, 19). Nový naturalizmus musí byt' podl'a všetkých realistov tiež „novým pluralizmom“. 6

V práci kolumbijskej školy pokračoval na univerzite Stony Brook v New Yorku d’alší Randallov žiak Justus Buchler (1914 - 1991), ktorý tam vychoval viacero žiakov, nadväzujúcich na jeho koncepciu naturalizmu aj dnes (Marsoobian, Wallace, Corrington 1991). Vplyv Buchlerovej inšpiratívnej „metafyziky prírodných komplexov“ (1966) však vel'mi nepresiahol hranice USA, podobne ako vplyv Marvina Farbera (1901 - 1980), Husserlovho študenta, ktorý preniesol centrum naturalizmu na univerzitu v Buffalo (štát New York), kde svojou prácou Naturalizmus a subjektivizmus (1959) etabloval „fenomenologický naturalizmus“.

\subsection{Santayana}

Najznámejším koryfejom amerického naturalizmu, a to aj za hranicami USA, sa stal George Santayana. Vypracoval originálny amalgám viacerých myšlienkových prúdov, začo ho označovali za eklektika (Hartshorne 1964). Tradične býva zarad’ovaný medzi kritických realistov (Kuklick 2001, 207 - 208) alebo pragmatistov (Stuhr 2000, 340 - 347), no v obidvoch prípadoch sa popri platonizme, skepticizme alebo materializme (Misak 2008, 125 - 143) akcentuje naturalizmus ako hlavná charakteristika jeho diela (Schneider 1963, 366 - 371; Conkin 1968, 405 - 474). ${ }^{7}$

\footnotetext{
${ }^{6}$ Ďalšími predstavitel'mi amerického kritického realizmu a zároveň naturalistami boli James B. Pratt (1875 - 1944), autor monografie Naturalizmus (1939); Durant Drake (1878 - 1933), autor práce Mysel' a jej miesto v prírode (1925); Charles A. Strong (1862 - 1940), autor Eseji o prirodzenom pôvode mysle (1930). Rodák z Minska Morris R. Cohen (1880 - 1947) spájal vo svojej filozofii vplyvy Santayanu, W. Jamesa a B. Russella, pričom vo svojej hlavnej práci Rozum a príroda (1931) sa tiež hlásil k naturalizmu ako formy racionalizmu.

${ }^{7}$ Najlepší súčasní znalci Santayanu nepochybujú o tom, že bol pragmatista, a teda aj jeho verziu naturalizmu označujú za pragmatistickú (Levinson 1992; Lachs 2006; Saatkamp in Marsoobian, Ryder 2004, 135 - 154). Santayana sám však označenie za pragmatistu rozhodne odmietal a pragmatizmus ostro kritizoval. Mal výhrady najmä voči Deweyho naturalizmu, ktorý označil za ,polovičatý a t’ažkopádny“" (Santayana 1925). Dewey kritiku odmietol a Santayanov naturalizmus označil za „nepodložený“ a poznačený prvkami dualizmu (Dewey 1927/1984, 80). K analýze tohto konfliktu pozri Shook (2003).
} 
Santayana čerpal svoj naturalizmus primárne z Lukrécia, Aristotela a Spinozu, sekundárne z Jamesa a Royca. Jeho prvú formuláciu ponúkol v monumentálnom pätzväzkovom Živote rozumu (1905), ${ }^{8}$ avšak naplno ju rozvinul až v Skepticizme a živočišnej viere (1923) a zavŕšil v štvorzväzkových Sférach bytia (1927 - 1940). Jadrom jeho koncepcie je presvedčenie, že 1) všetky naše poznatky pramenia v životnej činnosti, ktorú majú podporovat'; a že 2) aj všetok náš duchovný život (vedomie, imaginácia) sú pokračovaním tejto činnosti v rámci nášho bytia, ktoré sa celé odohráva v prírodnom bytí. To znamená, že niet žiadneho rozporu medzi prírodou a duchom, a takisto že duchovné formy bytia, aj ked’ sú „pokračovaním prírody inými prostriedkami“, nemožno a netreba redukovat' na čisto živočíšne formy bytia. Santayanov naturalizmus je nereduktívny a pluralistický. Náš rozum žije a pôsobí na všetkých úrovniach v množstve foriem, dokonca aj v umení a poézii.

\subsection{Logický pozitivizmus a postpozitivizmus}

Naturalizmus (vo všetkých variantoch) nadobudol v polovici dvadsiateho storočia status synonyma americkej filozofie ${ }^{9}$ najmä v opozícii $\mathrm{k}$ logickému pozitivizmu, ktorý naturalisti vnímali ako cudzí element na svojej vlastnej pôde (Jewett 2011). Rudolf Carnap (1891 - 1970) a jeho kolegovia ako pokračovatelia lingvistického obratu a konceptuálnej analýzy boli naozaj skôr antinaturalistami, hoci aj táto interpretácia sa začína v ostatnom čase menit'. Podl'a toho v logickom pozitivizme tiež môžeme nájst' prvky naturalizmu (Richards, Uebel 2007; Wagner 2012). ${ }^{10}$

Do kontextu naturalizácie v americkej filozofii - stále mimo pragmatizmu, alebo len čiastočne či v nepriamom spojení s ním - však zapadli postanalytickí filozofi Willard Van Orman Quine (1908 - 2000), jeho žiaci Wilfrid Sellars (1912 - 1989) a Donald Davidson (1917 - 2003), ba dokonca aj Thomas Kuhn (1922 - 1996) a jeho nasledovníci vo filozofii vedy. ${ }^{11}$ Išlo o naturalistický obrat najmä v oblasti epistemológie, filozofie vedy, filozofie jazyka a filozofie mysle (Kitcher 1992; Burge 1992). Spomedzi týchto filozofov naturalizmus najradikálnejšie a najexplicitnejšie forsíroval Quine (1969), no v jeho prípade išlo o redukcionistický (scientistický) variant, založený na nahradení filozofickej epistemológie vedami o poznaní, hoci sám Quine odmietal Carnapov redukcionizmus (Verhaegh 2018). Pre reduktívny materializmus

\footnotetext{
${ }^{8}$ Realistickí naturalisti oslavovali toto dielo ako „bibliu naturalizmu“.

${ }^{9} \mathrm{Z}$ naturalistických interpretácií by sme nemali vynechat' ani A. N. Whiteheada a jeho filozofiu procesu (Conner 2009), vyžaduje si to však samostatnú štúdiu.

${ }^{10}$ Spojivo medzi nimi by mohol predstavovat' E. Nagel. K naturalizmu mal najbližšie Otto Neurath (Uebel 1992). Vzt’ah logického pozitivizmu a naturalizmu si zasluhuje samostatnú štúdiu.

${ }^{11}$ Pozri Giere (1985); Quesada, Sosa (2007). Spomedzi Kuhnových nasledovníkov ide najmä o Larryho Laudana (nar. 1941), ktorý prišiel so svojím „,normatívnym naturalizmom“ (1990). K „umiernenému evolučnému naturalizmu“ sa hlásil aj sám Ronald Giere (1938 - 2020).
} 
a scientizmus Quineov naturalizmus zásadne odmietajú nielen pragmatisti (Ryder 2013), ale aj analytickí filozofi (Strawson 1985; Kim 1988; BonJour 1994). Naturalistická epistemológia $v$ tradičnom analytickom rámci však pokračuje d’alej (Rysiew 2020). ${ }^{12}$

\section{Naturalizmus v pragmatizme}

\subsection{V̌̌eobecná charakteristika}

Pragmatizmus je originálna filozofia, ktorá vykličila samostatne z pôdy americkej intelektuálnej tradície $\mathrm{v}$ druhej polovici devätnásteho storočia. Nebola odtrhnutá od európskych koreňov (F. Bacon, I. Kant, J. S. Mill, G. W. F. Hegel), no určujúci pre ňu bol „duch“, ktorý postrehol už A. de Tocqueville, ked’ písal o „filozofickej metóde Američanov“. Za jej hlavnú črtu označil „individuálne úsilie vlastného rozumu“ a to, že „ku všetkému nadprirodzenému majú neprekonatel’ný odpor“ (Tocqueville 2009, 620 - 621). Tento „duch“ nerezignoval na idey a ideály (ani náboženské), no primárne sa orientoval na praktický život, reálnu skúsenost', riešenie problémov, hodnoty demokratického komunitného života, utváranie nových možností a príležitostí, individuálne životné štastie atd'. Takto musela byt' orientovaná aj filozofia, ak chcela byt' relevantná pre život - realisticky, empiristicky, experiencialisticky a v konečnom dôsledku naturalisticky. ${ }^{13}$

Pragmatizmus je pluralitná antidualistická filozofia. U Peircea vyrástol z prírodovedy, u Jamesa zo starosti o dušu človeka, u Deweyho zo záujmu o kultiváciu spoločnosti. Všetci svojím spôsobom vyšli z poňatia prírody a cez poňatie človeka dospeli ku koncepcii kultúry ako organickej súčasti prírody so všetkými jej fenoménmi (myslou, vedomím, rozumom, poznaním, morálkou, hodnotami, náboženstvom atd'.) - ku koncepcii „kulturálneho naturalizmu“(Alexander 2019). ${ }^{14}$ Ak pôvodne boli východis-

\footnotetext{
${ }^{12}$ Quineov naturalizmus si našiel svojich obhajcov. Z nich najaktívnejší je Hilary Kornblith (1999; 2014). Nemenej živý je naturalizmus obsiahnutý vo filozofii W. Sellarsa, ktorý sa dokonca posunul do centra diskusií v rámci neopragmatizmu. Ten však nemôže byt’ predmetom tejto štúdie, rovnako ako naturalizmus D. Davidsona.

${ }^{13}$ Americká filozofia nastolila problém prekonávania dualizmu myslenia a činu, ideálu a skutočnosti, viery a vedy, technológie a humanizmu. V jej myšlienkovej tradícii sa prelínajú dva prúdy romantizmus a materializmus -, ktoré v Európe stáli proti sebe a ktorých spojenie sa stalo výzvou pre pragmatizmus (Goodman 1990; Smith 1992).

${ }^{14}$ „Kulturálny naturalizmus“ je Deweyho termín, ktorý prvýkrát použil v roku 1938 vo svojej Logike (Dewey 1986, 28). Neskôr v korešpondencii s Corlissom Lamontom (1902 - 1995) napísal: „Začal som uvažovat' o svojej vlastnej pozícii ako o kulturálnom alebo humanistickom naturalizme..." (Dewey 1940, 13667). Takto chcel nazvat’ aj svoju novú knihu, ktorú v tom čase písal (1941 - 1942), ale ktorej rukopis sa stratil. Nakoniec sa po šest'desiatich rokoch našiel a vyšiel pod názvom Nemoderná a moderná filozofia (Dewey 2012).
} 
kovými pojmami pragmatistického naturalizmu „skúmanie“ (Peirce) a potom „skúsenost““ (James, Dewey), d’alší vývoj postavil do centra pojem „kultúrnych praktík“.

Vzt’ah pragmatizmu a naturalizmu je inherentný, ale asymetrický: každý pragmatizmus je (aspoň do istej miery) naturalizmom, nie však naopak..$^{15}$ Vlastne ide o podobu a mieru naturalizmu v pragmatizme, takže podl'a niektorých je práve ,plnokrvný naturalistický pragmatizmus“ jeho najlepším variantom (Ryder 2013). Nie je to klasický naturalizmus v duchu kartezianizmu, ani v duchu novšieho naturalizmu darvinovského či postdarvinovského typu. Je to antiautoritarizmus ako jadro pragmatizmu, čo odlišuje tento naturalizmus od iných typov naturalizmu (Bagger 2018, 19 - 25). Jeho spoločným menovatel'om je odmietanie akejkolvvek mimol'udskej autority - nadprirodzenej, človekom nevytvorenej, alebo aj fiktívnej, človekom vytvorenej-, ktorej by sa mal človek klaňat' (Rorty 1999). Dokonca ani sama príroda tu nestojí voči človeku ako absolútna metafyzická realita, voči ktorej je človek bezmocný, ale skôr ako niečo, čo je súčast'ou l'udských interaktívnych praktík. Takýto charakter pragmatistickej filozofie dáva naturalizmu d’alší podstatný prívlastok - nereduktívny. To znamená, že pragmatisti sú naturalisti bez toho, aby upadali do reduktívneho materializmu či scientizmu alebo sa dogmaticky stavali do opozície voči idealizmu či spiritualizmu. Ak je kultúra „pokračovaním prírody inými prostriedkami“, tak všetky kultúrne fenomény (veda, náboženstvo, umenie, filozofia atd'.) „patria“ do prírody a dajú sa pochopit' ako „prirodzené“, i ked’ sú produktom l’udských kultúrnych praktík.

\subsection{Naturalizmus v klasickom pragmatizme}

Rekonštruovat' naturalizmus Charlesa Sandersa Peircea bolo dlho interpretačným problémom. Prišiel s ním T. A. Goudge (1950), ktorý (nie celkom neopodstatnene) založil svoju koncepciu „2 Peirceov“ na opozícii medzi jeho teóriou skúmania, metodológiou a logikou vedy na jednej strane (Peirce-naturalista), a metafyzikou, etikou, estetikou a teológiou na druhej strane (Peirce-transcendentalista). Jednotliví interpretátori sa následne pridávali raz sem, raz tam, alebo sa pokúšali toto rozdelenie prekonat' (Hookway 1985), respektíve ignorovat' a vytvorit' úplne inú interpretáciu (Murphey 1961). V každom prípade podstatná miera a špecifická podoba naturalizmu u Peircea sú nespochybnitel'né a týkajú sa troch rovín: metafyzickej, metodologickej aj teologickej (Giladi 2019). ${ }^{16}$ V metafyzickej rovine je Peirceov naturalizmus blízky spinozizmu a jeho rámcom je synechizmus - Peirceova koncepcia kontinuity všetkého bytia. $\mathrm{V}$ metodologickej rovine je to jeho experimentalizmus a koncepcia vedy ako

\footnotetext{
${ }^{15} \mathrm{O}$ rozdieloch medzi nimi pozri Ryder (2002).

${ }^{16}$ Peirce ako prírodovedec bol jednoznačne naturalistom a v súlade s tým je aj Peirce ako filozof pragmatista.
} 
vyvíjajúcej sa sebakorektívnej praktiky. V teologickej rovine je naturalistickým idealistom (podl'a niektorých však antinaturalistom), ktorý aj „ducha“ vysvetl'uje z prírody, respektíve naopak, nerobí teda medzi nimi zásadný ontologický rozdiel, ked’ uvažuje o evolučnej kozmológii a láske (Dea, Haydon 2019). Práve táto tretia podoba naturalizmu u Peircea spôsobuje najviac problémov. ${ }^{17}$

Miera a podoba naturalizmu v pragmatizme Williama Jamesa sú takisto unikátne a majú najd’alej k ,čistému“ naturalizmu. Podl'a niektorých interpretácí sa James dokonca ešte radikálnejšie odklonil od naturalizmu svojím humanizmom a psychologizmom, teda dôrazom na vieru, individuálnu skúsenost' a existenciálnu nádej. ${ }^{18}$ Jeho holizmus je antiscientizmus, ktorý poukazuje na limity vedy, je zameraný proti reduktívnemu materializmu. Takýto deterministický naturalizmus James kritizoval a odmietal ako „krutý“, antihumánny fatalizmus. Rešpektoval l'udskú potrebu viery, a to aj náboženskej, ba vo svojich úvahách o náboženskej skúsenosti nevylučoval ani supranaturálne fenomény. Na druhej strane bol proti abstraktnosti absolútneho idealizmu a racionalizmu, lebo chcel zachovat' konkrétnost' naturalizmu. Pokúšal sa o akúsi „tretiu cestu" medzi naturalizmom a antinaturalizmom (Lamberth 2001). Naturalistické boli už jeho Princípy psychológie (1890), ${ }^{19}$ ale svoj nereduktívny naturalizmus najplnšie rozvinul v koncepcii radikálneho empirizmu (James 1976) a pluralistického univerza (James 1977). Aj spiritualita podl'a neho patrí do nášho života celkom prirodzene a je prejavom osobného temperamentu. V Jamesovom prípade môžeme takisto hovorit' o náboženskom naturalizme, založenom na „dvojúrovňovom pohl'ade“ (Cooper 2002), teda na odlíšení medzi naturalistickým vysvetlením vzniku, vývinu a existencie náboženstva od jeho duchovnej kultúrnej hodnoty (Bagger 2018, 44 - 65).

Najsystematickejším naturalistom spomedzi zakladatel'ov pragmatizmu bol John Dewey, ${ }^{20}$ ktorý dokonca preferoval naturalizmus ako meno pre svoju filozofiu pred pragmatizmom. Evolučným naturalistom (naturalizovaným hegeliánom) sa stal pod vplyvom darvinizmu i Jamesa, čo sa prejavilo už v jeho raných psychologických prácach, najmä v inšpiratívnej eseji o reflexnom oblúku (Dewey 1896/1972). Vplyv darvinizmu na filozofiu univerzalizoval d’alej (Dewey 1909/1996) smerom k „empirickému

\footnotetext{
${ }^{17}$ R. S. Corrington (1993) ju nazval extatickým naturalizmom. Prevládla však interpretácia, ktorá hovorí celkom pokojne o Peirceovom náboženskom naturalizme (Raposa 2018).

${ }^{18}$ R. M. Gale (1997; 2004) vel'mi jednostranne interpretuje Jamesa skôr ako antinaturalistu v opozícii k Deweymu a akúkol'vek naturalizáciu Jamesovej filozofie pripisuje len Deweymu.

${ }^{19}$ Podl'a O. Flanagana $(1984,24)$ bola naturalistická aj jeho filozofia mysle, podl’a ktorej „mysel’ nemá žiadne metafyzicky zvláštne vlastnosti“, ktoré by nemal materiálny svet. W. Cooper (2002, $45,64)$ oponuje tejto interpretácii ako neplauzibilnej a poukazuje skôr na Jamesovu inklináciu k panpsychizmu.

${ }_{20}$ George Herbert Mead (1863 - 1931), často označovaný za štvrtého klasika (Shook, Margolis 2006; Stuhr 2000), bol „sociálnym naturalistom“ vo svojej teórii konania, subjektu a jazyka (Eames 1977; Joas, Huebner 2016).
} 
naturalizmu“ ako nazval svoju metódu i metafyziku v kl'účovom diele Skúsenost' a príroda (Dewey 1925/1988, 4, 62). Jadrom Deweyho pragmatistického naturalizmu je pojem skúsenosti, koncipovaný ako súbor l’udských praktík, prostredníctvom ktorých sme v priamych (primárnych) interakciách (transakciách) s prírodnou realitou ako jedinou a ultimátnou realitou, $v$ ktorej žijeme. Naša skúsenost' je však nielen adaptívna, ale aj produktívna. Jej výsledkom je transformácia prírody na kultúru. Kultúra emerguje z prírody a zahŕňa samostatné formy, vytvárajúce reflexiu i projekciu bytia (filozofia, veda, umenie, náboženstvo). Spiritus agens i spiritus movens všetkých l'udských praktík a transakcií je inteligencia, najprv ako čisto prírodný, potom ako sociokultúrny fenomén. Niet žiadnej ontologickej priepasti medzi prírodou a skúsenostou (kultúrou), práve naopak, kontinuita medzi nimi umožňuje tak „kultiváciu prírody“, ako aj „naturalizáciu kultúry“ vo všetkých smeroch i významoch, konštruktívnych i deštruktívnych. Táto antidualistická naturalistická metafyzika sa stala pre Deweyho východiskom pre jeho naturalistickú filozofickú koncepciu politiky (Verejnost' a jej problémy, 1927), poznania (Hladanie istoty, 1925), morálky (Etika, 1932), náboženstva (Spoločná viera, 1934), ${ }^{21}$ umenia (Umenie ako skúsenost', 1934), vedy (Logika: teória skúmania, 1938) a hodnôt (Teória hodnotenia, 1939). ${ }^{22}$

\section{Záver}

Podl'a pragmatizmu je naturalizmus kultúrnym produktom, l’udským výtvorom, tak ako každý -izmus. Je dôsledkom a prejavom modernej kultúry, v ktorej dominantnou sociokultúrnou praktikou a autoritou je veda. Má svoj slovník ako nástroj na interpretáciu sveta. Naturalizovat 'čokol'vek znamená lokalizovat' to do prírody, označit' za prírodný jav a vysvetl'ovat' prirodzene l'udskými silami, nielen metódami prírodných vied. ${ }^{23}$

Americká filozofia priniesla celý vejár naturalistických prístupov. Ich súčast'ou boli realizmus a empirizmus, ale aj romantizmus a liberalizmus, čím táto filozofia smerovala $\mathrm{k}$ prekonaniu hlavných úskalí iných typov naturalizmu: redukcionizmu, materializmu / fyzikalizmu, scientizmu / pozitivizmu. Špecifikum pragmatistického naturalizmu tkvie $\mathrm{v}$ jeho antiautoritarizme a antiabsolutizme, čím sa spája s humanizmom ako odmietnutím l’udskej závislosti od mimol’udských autorít, či už človekom

\footnotetext{
${ }^{21}$ Zásadný rozdiel medzi Deweyho a Jamesovým náboženským naturalizmom spočíva v dôraze na sociálnu sociálnu skúsenost' oproti individuálnej (pozri Pihlström 2020).

${ }^{22}$ Sidney Hook (1902 - 1989), Deweyho najvýznamnejší žiak, pokračoval v rozvíjaní jeho pragmatistického naturalizmu ako sekularizmu a sekulárneho humanizmu (Cotter 2004).

${ }^{23} \mathrm{Za}$,neprírodné“ sa tradične považovalo: 1) nadprirodzené (niečo, čo nevytvorila príroda, ale vyššia sila, Boh); 2) nemateriálne (nefyzikálne, mentálne, duchovné, neempirické, nadzmyslové, mimo skúsenosti - rozum, duch, duša, mysel', vedomie atd'.); 3) kultúrne (ako arbitrárne, subjektívne, človekom vytvorené - umelé, jazykové a pod.).
} 
vytvorených, alebo nie. Základom takejto koncepcie je poňatie kultúry ako pokračovania prírody inými, lud'mi vytvorenými prostriedkami. Pragmatistický naturalizmus je kulturálny, nereduktívny, pluralistický a antidualistický, prekonávajúci dualizmus prírodného determinizmu a sociokultúrneho normativizmu.

\section{Literatúra}

ALEXANDER, T. M. (2019): Dewey's Naturalistic Metaphysics. In: Fesmire, S. (ed.): The Oxford Handbook of Dewey. Oxford: Oxford University Press, 25 - 52.

BAGGER, M. (ed.) (2018): Pragmatism and Naturalism. New York: Columbia University Press.

BONJOUR, L. (1994): Against Naturalized Epistemology. Midwest Studies in Philosophy, XIX, 283 - 300. DOI: http://dx.doi.org/10.1111/j.1475-4975.1994.tb00290.x

BURGE, T. (1992): Philosophy of Language and Mind: 1950 - 1990. The Philosophical Review, 101, 1, 3 - 51. DOI: $10.2307 / 2185043$

BUCHLER, J. (1966): Metaphysics of Natural Complexes. New York: Columbia University Press.

CAHILL, K. M. - RALEIGH, T. (eds.) (2018): Wittgenstein and Naturalism. New York - London: Routledge.

CARO, M. DE - MACARTHUR, D. (eds.) (2010): Naturalism and Normativity. New York: Columbia University Press.

CLARK, K. J. (ed.) (2016): The Blackwell Companion to Naturalism. Oxford: Wiley Blackwell.

CONKIN, P. K. (1968): Puritans \& Pragmatists. New York: Dodd, Mead \& Company.

CONNER, D. E. (2009): Whitehead the Naturalist. American Journal of Theology \& Philosophy, $30(2), 168-186$.

COOPER, W. (2002): The Unity of William James's Thought. Nashville: Vanderbilt University Press.

CORRADINI, A. - GALVAN, S. - LOWE, E. J. (eds.) (2006): Analytic Philosophy Without Naturalism. London - New York: Routledge.

CORRINGTON, R. S. (1992): Nature and Spirit. New York: Fordham University Press.

CORRINGTON, R. S. (1993): An Introduction to C. S. Peirce: Philosopher, Semiotician and Ecstatic Naturalist. Lanham: Rowman and Littlefield.

COTTER, M. J. (ed.) (2004): Sidney Hook Reconsidered. Amherst - New York: Prometheus Books.

CRAIG, W. L. - MORELAND, J. P. (eds.) (2000): Naturalism. A Critical Analysis. London - New York: Routledge.

DEA, S., HAYDON, N. (2019): From the Experimentalist Disposition to the Absolute. Peirce's Pragmatic Naturalism. In: Giladi, P. (ed.): Responses to Naturalism. Critical Perspectives from Idealism to Pragmatism. New York - London: Routledge, 167 - 181.

DEWEY, J. (1896/1972): The Reflex Arc Concept in Psychology. In: Boydston, J. O. (ed).: The Early Works of John Dewey, Volume 5: 1882 - 1898. Carbondale: Southern Illinois University Press, $96-110$.

DEWEY, J. (1909/1996): Vplyv darvinizmu na filozofiu. In: Višňovský, E. - Mihina, F. (eds.): Pragmatizmus. Malá antológia filozofie XX. storočia, zv. 1. Bratislava: IRIS, 335 - 344.

DEWEY, J. (1925/1988): Experience and Nature. In: Boydston, J. O. (ed).: The Later Works of John Dewey, Volume 1, 1925. Carbondale: Southern Illinois University Press.

DEWEY, J. (1927/1984): Half-hearted Naturalism. In: Boydston, J. O. (ed).: The Later Works of John Dewey, Volume 3, 1927 - 1928. Carbondale: Southern Illinois University Press, 73 - 81.

DEWEY, J. (1938/1986): Logic: The Theory of Inquiry. In: Boydston, J. O. (ed).: The Later Works of John Dewey, Volume 12, 1938. Carbondale: Southern Illinois University Press.

DEWEY, J. (1940): Correspondence. John Dewey to Corliss Lamont, September 6, 1940. In: Corliss Lamont papers, 1891 - 1993, Columbia University Library, 13667. 
DEWEY, J. (2012): Unmodern Philosophy and Modern Philosophy. Carbondale: Southern Illinois University Press.

ELDRIDGE, M. (2004): Naturalism. In: Marsoobian, A. T. - Ryder, J. (eds.): The Blackwell Guide to American Philosophy. Oxford: Blackwell Publishing, 52 - 72.

FARBER, M. (1959): Naturalism and subjectivism. New York: State University of New York Press.

FLANAGAN, O. (1984): The Science of Mind. Cambridge (Mass): The MIT Press.

FOX, R. W. - KLOPPENBERG, J. T. (eds.) (1995): A Companion to American Thought. Oxford: Blackwell.

GALE, R. M. (1997): John Dewey's Naturalization of William James. In: Putnam, R. A. (ed.): The Cambridge Companion to William James. Cambridge: Cambridge University Press, 49 - 68.

GIERE, R. N. (1985): Philosophy of Science Naturalized. Philosophy of Science, 52 (3), 331 - 356. DOI: https://doi.org/10.1007/BF00486661

GILADI, P. (ed.) (2019): Responses to Naturalism. Critical Perspectives from Idealism to Pragmatism. New York - London: Routledge.

GOODMAN, R. B. (1990): American Philosophy and the Romantic Tradition. Cambridge: Cambridge University Press.

GOUDGE, T. A. (1950): The Thought of C. S. Peirce. New York: Dover Publications.

HARTSHORNE, C. (1964): Santayana's Defiant Eclecticism. The Journal of Philosophy, 61 (1), $35-44$.

HOOKWAY, C. (1985): Peirce. London - New York: Routledge.

JAMES, W. (1976): Essays in Radical Empiricism. Cambridge: Harvard University Press.

JAMES, W. (1977): A Pluralistic Universe. Cambridge: Harvard University Press.

JEWETT, A. (2011): Canonizing Dewey: Columbia Naturalism, Logical Empiricism, and the Idea of American Philosophy. Modern Intellectual History, 8 (1), 91 - 125. DOI: https://doi.org/10.1017/S1479244311000060

JOAS, H. - HUEBNER, D. R. (eds.) (2016): The Timeliness of George Herbert Mead. Chicago: The University of Chicago Press.

KIM, J. (1988): What is Naturalized Epistemology? In: Tomberlin, J. E. (ed.): Philosophical Perspectives, 2, Atascadero: Ridgeview Publishing Co., 381 - 406.

KIM, J. (2003): The American Origins of Philosophical Naturalism. Journal of Philosophical Research, Issue Supplement, 83 - 98. DOI: https://doi.org/10.5840/jpr200328Supplement28

KITCHER, P. (1992): The Naturalists Return. The Philosophical Review, 101 (1), 53 - 114. DOI: $10.2307 / 2185044$

KORNBLITH, H. (1999): In Defense of a Naturalized Epistemology. In: Greco, J. - Sosa, E. (eds.): The Blackwell Guide to Epistemology. Malden: Blackwell, 158 - 169.

KORNBLITH, H. (2014): A Naturalistic Epistemology: Selected Papers. Oxford: Oxford University Press.

KUKLICK, B. (2001): A History of Philosophy in America. Oxford: Clarendon Press.

KURTZ, P. (ed.) (1968): American Philosophy in the Twentieth Century. New York: The MacMillan Company.

LAMBERTH, D. C. (2001): Pragmatism and Naturalism: An Inevitable Conjunction? Cognitio: Revista de Filosofia, 2 (2), 74 - 87.

LAUDAN, L. (1990): Normative Naturalism. Philosophy of Science, 57 (1), 44 - 59.

LEVINSON, H. S. (1992): Santayana, Pragmatism, and Spiritual Life. Chapel Hill - London: The University of North Carolina Press.

MADDEN, E. H. (1963): Chauncey Wright and the Foundations of Pragmatism. Seattle: University of Washington Press.

MARSOOBIAN, A. - WALLACE, K. - CORRINGTON, R. S. (eds.) (1991): Nature's Perspectives. New York: State University of New York Press.

MARSOOBIAN, A. T. - RYDER, J. (eds.): The Blackwell Guide to American Philosophy. Oxford: Blackwell Publishing. 
MIHINA, F. (1992): Duch americkej filozofie. Filozofia, 47 (11), 658 - 664.

MISAK, C. (ed.) (2008): The Oxford Handbook of American Philosophy. Oxford: Oxford University Press.

MURPHEY, M. G. (1961): The Development of Peirce's Philosophy. Cambridge: Harvard University Press.

PIHLSTRÖM, S. (2020): Pragmatic Realism, Religious Truth, and Antitheodicy. Helsinki: Helsinki University Press.

QUESADA, F. M. - SOSA, E. (eds.) (2007): Naturalized Epistemology and Philosophy of Science. Amsterdam and New York: Rodopi.

QUINE, W. V. O. (1969). Ontological Relativity and Other Essays. New York: Columbia University Press.

RAPOSA, M. L. (2018): Instinct and Inquiry. A Reconsideration of Peirce's Religious Naturalism. In: BAGGER, M. (ed.): Pragmatism and Naturalism. New York: Columbia University Press, $27-43$.

RICHARDSON, A. - UEBEL, T. (eds.) (2007): The Cambridge Companion to Logical Empiricism New York: Cambridge University Press.

RORTY R. (1999): Pragmatism as Anti-Authoritarianism. Revue Internationale de Philosophie, 53 (207), $7-20$.

RYDER, J. (ed.) (1994): American Philosophic Naturalism in the Twentieth Century. Amherst: Prometheus Books.

RYDER, J. (2002): Zmierenie pragmatizmu a naturalizmu. Filozofia, 57 (2), 123 - 136.

RYDER, J. (2013): The Things on Heaven and Earth. New York: Fordham University Press, 2013.

RYSIEW, P. (2020): Naturalism in Epistemology. [online] Dostupné na: https://plato.stanford.edu/ entries/epistemology-naturalized/\#toc (Navštívené 23. 8. 2020).

SAATKAMP, H. J., Jr. (2004): George Santayana, 1863 - 1952. In: Marsoobian, A. T. - Ryder, J. (eds.): The Blackwell Guide to American Philosophy. Oxford: Blackwell Publishing, $135-154$.

SANTAYANA, G. (1925): Dewey's Naturalistic Metaphysics. Journal of Philosophy, 22 (6), $678-679$

SELLARS, R. W. (1922): Evolutionary Naturalism. Chicago - London: The Open Court Publishing Company.

SHAPIRO, D. (1964): Ethan Allen: Philosopher-Theologian to a Generation of American Revolutionaries. The William and Mary Quarterly, 21 (2), 236 - 255.

SHOOK, J. (2003): The Possibility of an Empiricist Naturalism: Dewey and Santayana. Bulletin of the Santayana Society, 21, $1-7$.

SHOOK, J. - MARGOLIS, J. (eds.) (2003): A Companion to Pragmatism. Oxford: Blackwell Publishing.

SMITH, J. E. (1992): America's Philosophical Vision. Chicago - London: The University of Chicago Press.

STRAWSON, P. F. (1985): Skepticism and Naturalism: Some Varieties. New York: Columbia University Press.

STROUD, B. (1996): The Charm of Naturalism. Proceedings and Addresses of the American Philosophical Association, 70 (2), 43 - 55.

STUHR, J. J. (ed.) (2000): Pragmatism and Classical American Philosophy. New York: Oxford University Press.

SCHNEIDER, H. W. (1963): A History of American Philosophy. New York: Columbia University Press.

TOCQUEVILLE, A. DE (2009): O demokracii v Amerike. Bratislava: Kalligram.

UEBEL, T. (1992): Overcoming Logical Positivism from Within: The Emergence of Neurath's Naturalism in the Vienna Circle's Protocol Sentence Debate. Aamsterdam - Atlanta: Rodopi. 
VERHAEGH, S. (2018): Working from Within. The Nature and Development of Quine's Naturalism. New York: Oxford University Press.

WAGNER, P. (ed.) (2012): Carnap's Ideal of Explication and Naturalism. Houndmills - Basingstoke: Palgrave Macmillan.

WRIGHT, C. (1871/1878): Philosophical Discussions. New York: Henry Holt and Company.

Táto práca bola podporená Agentúrou na podporu výskumu a vývoja na základe Zmluvy č. APVV$18-0178$.

Emil Višňovský

Univerzita Komenského v Bratislave

Filozofická fakulta

Katedra filozofie a dejín filozofie

Gondova 2

81102 Bratislava 1

Slovenská republika

e-mail: emil.visnovsky@uniba.sk

ORCID ID: https://orcid.org/0000-0003-1586-4015 